The $5^{\text {th }}$ International Conference on Family Business and Entrepreneurship

\title{
WOMEN IN TECH ENTREPRENEURSHIP RESEARCH - LITERATURE REVIEW
}

\author{
Fadhilah $^{1^{*}}$, Fandya Rasmita Diniswara ${ }^{2}$, Mareta Putri Hasyatamma ${ }^{3}$, Nafisa \\ Nurfadila ${ }^{4}$ \\ ${ }^{1,2,3,4}$ Sepuluh Nopember Institute of Technology, Corresponding author: fadhilahadam4@ gmail.com
}

\begin{abstract}
:
In this era, women have become important players in the field of business and entrepreneurship. Technology provides opportunities for women to expand their social networks by creating new opportunities for businesses where entrepreneurial barriers can be overcome by adopting technology, particularly in developing countries. The more research and publication on women entrepreneurship with 24 journal selected from 68 journal available, this makes researchers feel the need to study to find out how and the extent of the development of women entrepreneurs in the field of technology. The data collection in this study was taken from Scopus web by entering the keywords that the author used to get the desired amount of publication and information. This study uses bibliometric analysis method conducted using co-authorship and co-citation analysis with the help of VOSviewer software. This study will also mention which developing countries have published and researched on this topic as well as the extent of relationships between authors in each existing journal.
\end{abstract}

Keywords : Entrepreneurship, Women, Technology, Bibliometrics.

\section{Introduction}

Women entrepreneurs have become important players in the sphere of entrepreneurship and show the increasingly recognized role of women in the economic development of a country (Andrizal, 2018). Although the number is still small when compared to male-owned businesses, it shows that women no longer adhere to the stereotype that only men can be the breadwinners in the family. According to a survey based on the Mastercard Index of Women Entrepreneurs (MIWE) quoted from (Liputan6.com, 2018) said that women entrepreneurs tend to experience better development in developed countries than developing countries. Research on women entrepreneurs in developing countries still has limited research compared to research in developed countries. This happens because women entrepreneurs in developing countries always face obstacles such as culture, training, capital, technology, experience and government procedures (AW, 2017). Compared to developing countries, women entrepreneurs in developed countries are better able to take advantage of the vast resources and opportunities, including access to capital, financial services, and academic programs. Today's technological developments are familiar to all circles. According to (Donner \& Escobari, 2010) said that technological innovation can help in increasing market efficiency and the development of new business ventures. One of the efforts to support women's entrepreneurship is to facilitate women's empowerment in information communication technology ( Crittenden, Crittenden, \& Ajjan, 2019). Information Communications Technology (ICT) provides women to expand their social networks which can create new opportunities for business where barriers to entrepreneurship can be overcome by adopting technology or ICT. Having access to technology can help women to be able to collect information about financing and markets that is useful for their business (Hinson, 2011). Based on the background, this study will examine how the development of female entrepreneurship in technology adoption using bibliometric analysis in developing countries. The author chose to conduct a literature 
review using bibliometric analysis because this method can find out publication information systematically and easily find out how the structure of publications and research progress. With the characteristics of the published literature, bibliometrics can reveal the academic strength of an institution as well as the potential of citation or co-citation models, thereby encouraging exploration and clarification of the main research content for the advancement of a particular discipline (Ferreira, 2014). Based on the previous explanation, this research is expected to be able to contribute to the development of science and provide information on the development trend of technology adoption in women's entrepreneurship, so that it can provide recommendations and directions for further research on what research should be developed in this field. This research can also serve as a reference material in conducting bibliometric studies both in the field of similar research and other research fields.

\section{Literature Review}

\section{Bibliometrics}

Bibliometrics are taken based on the basic word biblio or commonly known as bibliography which in other words as a book or bibliography, then the word metrics related to measuring. Therefore, the term bibliometrics can be inferred into measuring or analyzing books through mathematical and statistical approaches (Himawanto, 2015). The understanding of Bibliometric itself is to analyze previously published journals in a systematic way both written and digital (Royani \& Idhani, 2018). Bibliometric is also the oldest study in library science and is included in quantitative studies. Bibliometric is also an application of mathematical and statistical methods for books and other communication media (Glanzel, 2003). Bibliometric studies can show a greater understanding of all sciences, revealing the names of authors who most often write in disciplines, countries, languages more commonly used in the field of science (Nuryudi, 2016). To get the concept of science in a document depends on the word (co-word). Co-word analysis aims to examine the content, patterns, and trend trends of a document by measuring the strength of the term (De Looze \& Lemarie, 1997). These keywords can be determined by the author and with the number of keywords there will be many documents that will appear.

\section{Women's Entrepreneurship}

Entrepreneur is derived from the French verb "entrepende" which means 'to undertake', 'to attempt', 'to try in hand', 'to contract for', or 'to adventure', 'to try', 'to risk'. This term was first proposed by Richard Cantillon in 1755 and became increasingly popular when used by J.B Say in 1803 to define entrepreneurs who can develop economic resources from low to high productivity and produce a lot of output (Agustiyani, 2014). The importance of women's entrepreneurship today has been well documented in the academic literature and government policy documentation in today's world. Socio-economic background itself is an important factor that influences women to start a business (Roy \& Manna, 2014). According to (Buttner \& Moore, 1997) said that the main reason or driver of entrepreneurial decision making by women is because they can determine their own destiny, have expectations of recognition, self-esteem, and career goals. Sometimes, women choose this kind of career path to discover their inner potential, gain self-satisfaction, and make the most of their free time. In addition, difficult economic conditions can also force women to become entrepreneurs. For developing countries themselves, recent evidence shows that the prevalence rate of female entrepreneurship tends to be relatively higher than in developed countries. This is traditionally explained by the fact that in developing countries women face higher barriers to entry into the formal labor market and must use entrepreneurship as a way out of unemployment or poverty. Although there are many challenges, women also have opportunities for entrepreneurship. Having a strong support system greatly helps women to enter and survive in entrepreneurial ventures.

\section{Technology Access for Women Entrepreneurs}

According to (Prasojo, 2011) information technology is defined as science in the field of computer based information and its development is very rapid. Of course, in business, it is necessary to keep up with the 
times with facilities and technological innovations so that female entrepreneurs can run and develop their businesses quickly. A study by the Indonesian Ministry of Women's Empowerment, in the field of technology, especially IT, showed that information and communication technology was still dominated by male and female gender, often only as objects. This is also related to issues regarding gender and technology, including issues that are important and big, especially those faced by women globally. Technology is an important reference as a means to empower women. However, there are also those who argue that IT is only for development in general and not specifically to empower women, especially in developing countries. According to (Kshetri, 2003) that as a social product, various technologies, one of which the internet is not free of values or culture. Of course, this will be a great opportunity for women who want to contribute and become entrepreneurs, especially in the field of technology that has dominated the market in today's era.

\section{Empowering Women Entrepreneurs through the Digital Industry and Technology}

The existence of technology helps human resources, especially women, to contribute in the field of trade and entrepreneurship. Technology can be used as a source of information as well as a place to market their products. The use of technology for business or entrepreneurship has flourished with an internet-based online business that is easy to reach even at home, so it is very flexible for most women who also have responsibilities at home. This is supported by the economic census data at the 2006 BPS which shows the number of SMEs is around 22,513,552. However, in 2008 the number of micro, small and medium enterprises was 46 million and it is known that $60 \%$ of the managers are women. From these data, it can be seen that the role of women is quite large in the economy and entrepreneurship which can create jobs. However, there are still factors that hinder the lack of development of the use of technology in entrepreneurship due to the lack of information and education about it. The efforts to integrate technology and women in the field of entrepreneurship need serious attention from the government. So that global understanding of women and their relation to the use of technology must be improved by supporting seminars or trainings for women entrepreneurs in the optimal use of technology. Other activities that also need to be carried out include increasing skills and knowledge on the use of technology, integrating gender issues in every community development program, especially business development from small to large businesses for women entrepreneurs.

\section{Research Method}

The research phase is divided into five main stages, starting from the preparation stage, the data collection stage, the descriptive analysis stage, bibliometric analysis and finally the conclusion draw. At the preparatory stage will be identified about the background and what problems to be researched will then be formulated into the main problems to be solved in the research. To support the basis of theory and discussion materials in the research, literature studies are also conducted. The data to be retrieved for this study comes from the Scopus database. Starting from searching using keywords, the combination of keywords that will be used is found in figure 1 .

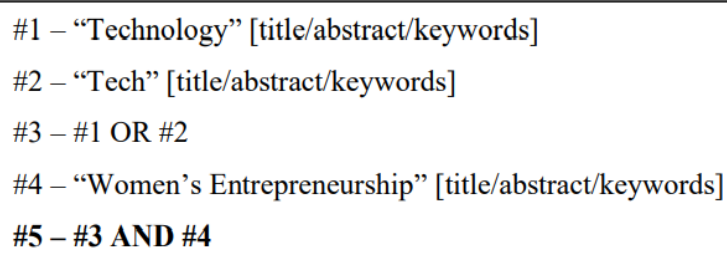

Figure 1. Scopus search queries writing plan

Please note that what is written in the Scopus search field is the most recent list of writing plans that is (\#5) with search content: ("Technology" OR "Tech") AND ("Women's Entrepreneurship") 


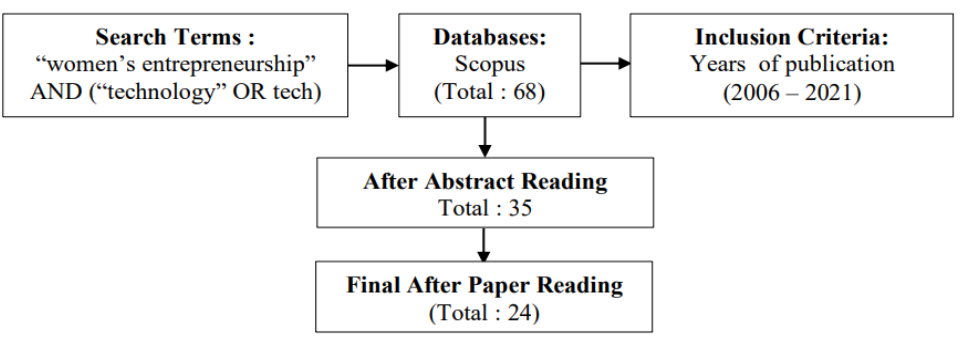

Figure 2. Literature study protocol

The criteria used during the search is the search year between 2006-2021, all publications with that keyword result in 68 publications. The search results are then downloaded and manually selected by reviewing the title, abstract, and keywords of each article to ensure that all articles to be used in accordance with the focus of the research to be conducted, obtained a final total of 24 articles of publication. The final result of the article data obtained will then be extracted and incorporated into vosviewer software for bibliometric analysts to perform. Keywords used for manual article selection are Entrepreneurship, Women, Technology. The next stage is the analysis of co-authorship and bibliometric co-citation, which is useful to know how the relationship between countries, authors, journals, topics or keywords is used, thus explaining how they relate to each other. In the next stage in general there will be three main presentations, namely the explanation of the results and conclusions of the research that has been conducted, followed by the provision of theoretical implications and managerial implications that can be produced and implemented based on the findings of the research conducted. Then give advice that serves to direct what should be prepared by the next research to improve and improve the current research.

\section{Results and Discussion}

\section{Documents by Year}

Based on the data in Figure 2 shows that research on women's entrepreneurship in technology adoption (women in tech) has existed since 2006. In 2007 there was no research on this topic, but starting in 2008, research began to be widely carried out and began to climb. higher in 2017 as many as 8 studies, but in 2018 it decreased again to only 3 studies. In 2019 it began to increase again to 11 studies, followed by 2020 the most research was 13 studies. Until mid-2021, it appears that there are still 7 studies that have been carried out. From the results of the analysis of the number of publications per year, it can be seen that research in the field of women in tech has a positive trend which can indicate that research in this field needs to be carried out.

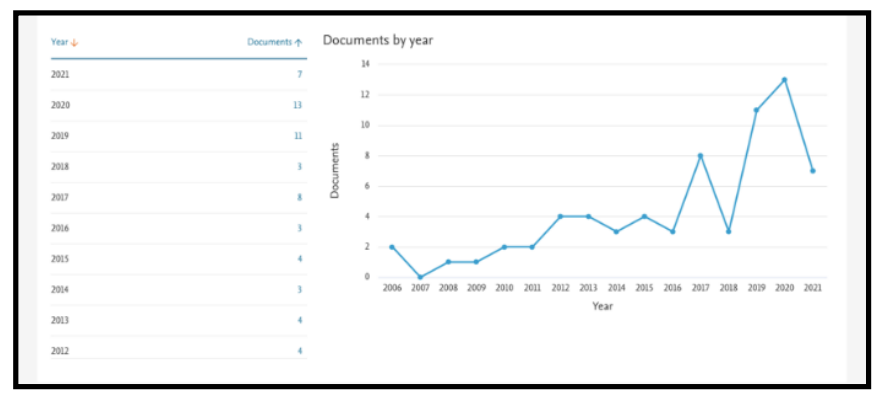

Figure 3. Document by Year

(Source: Data processing on Scopus, 19 June 2021)

\section{Document by country/territory}

Based on the data in Figure 3, the contributors to the results of the Woman Entrepreneur research in the 44 
field of technology indexed by Scopus in 2006-2021 are spread in 30 countries in the world including Indonesia, based on the results of the Scopus analysis there are details of the top 10 top 10 most based on the number of studies in that country, the first is United States or commonly known as the United States of America which is 10 articles, followed by India and Spain with the same number of 7 articles, then there are in Australia as many as 6 articles, Germany and Malaysia with the same number of 5 articles each, then Canada and United Kingdom with 4 articles each, and finally there are researches in Sweden as many as 3. While other countries namely Denmark, Indonesia, Norway, Switzerland with 2 and 16 other countries, namely Chile, China, Georgia, Iran, Italy, Netherlands, Nigeria, Oman, Peru, Philippines, Saudi Arabia, Singapore, South Africa tan, Turkey, United Arab Emirates, Uzbekistan as many as 1 article each, and the rest whose country is not identified as many as 6 articles.

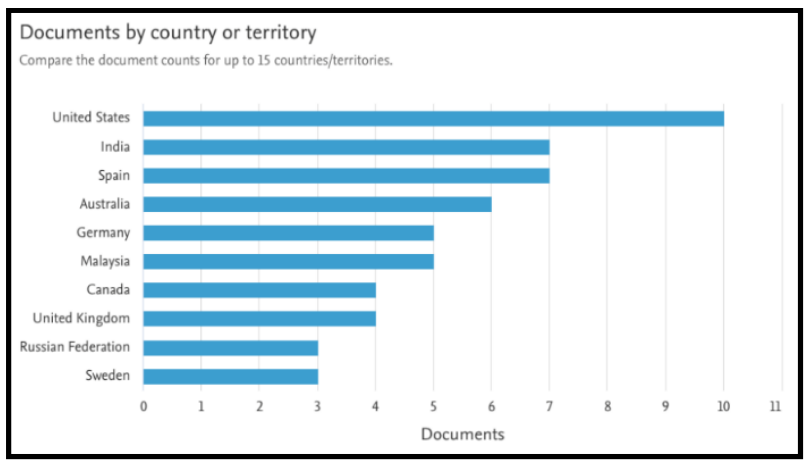

Figure 4. Country of Origin of Researcher

(Source: Data processing on Scopus, 19 June 2021)

\section{Document By Type}

Based on the data in Figure 5, it can be seen that the results of the analysis of documents published on the Scopus page with the title "Women's entrepreneurship" AND ("technology" OR tech), obtained as many as 68 documents spread over 6 types of documents. The most common types found in this title are Articles with a percentage of $54.4 \%$ or 37 articles, the next most are Conference Paper documents with a percentage of $20.6 \%$ or 14 Conference Papers, the third is Book Chapters with a percentage of $11.8 \%$ or a number of 8 Book Chapters, then the Conference Review and Review document types which have the same percentage of 5.9\% or a number of 4 each in each type, and the last is the Book document type, which is a book with the smallest percentage of $1.5 \%$ or a total of one book.

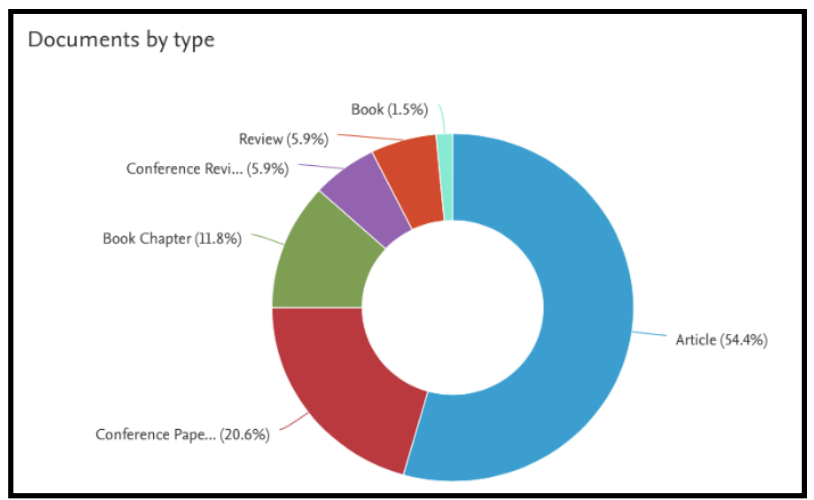

Figure 5. Types of Published Documents

(Source: Data processing on Scopus, 19 June 2021)

\section{Research Subjects}

Scopus indexed research subjects in $2006-2021$ as in Figure 6 the highest subjects were business, 
management, and accounting as much as 28.6 percent; Second social sciences by 18.0 percent; Third, economics, econometrics and finance by 15.8 percent; Fourth, computer science or computer science as much as 10.5 percent; Fifth, engineering Engineering as much as 6.0 percent. Therefore, this research is more dominant including in the fields of business studies, management, and accounting.

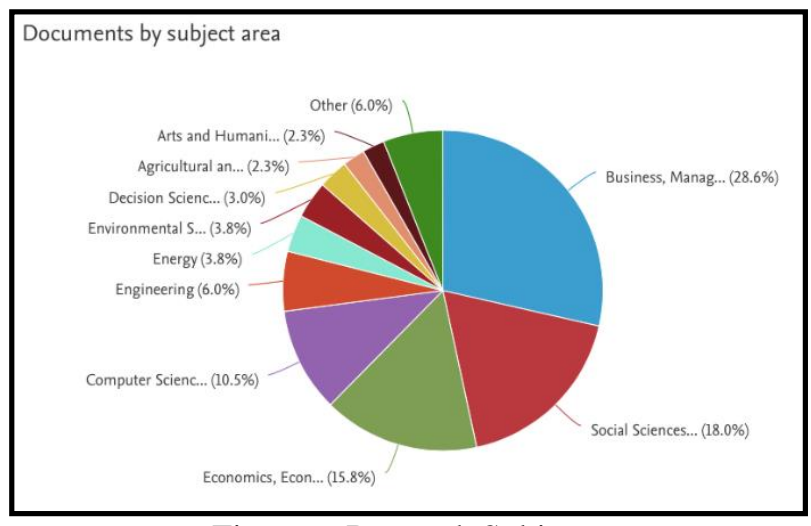

Figure 6. Research Subjects

(Source: Data processing on Scopus, 19 June 2021)

\section{Bibliometric Co-Authorship Analysis}

In accordance with Figure 7 in analyzing research trends using VOS viewer with the co-authorship feature with unit of analysis: countries can be used to find out which countries have researched the discussion on women in tech. Countries that will emerge later will be related when several researchers conduct research simultaneously. The data that has been used comes from 24 research article data. The following are the results of the co-authorship conducted on VOSviewer:

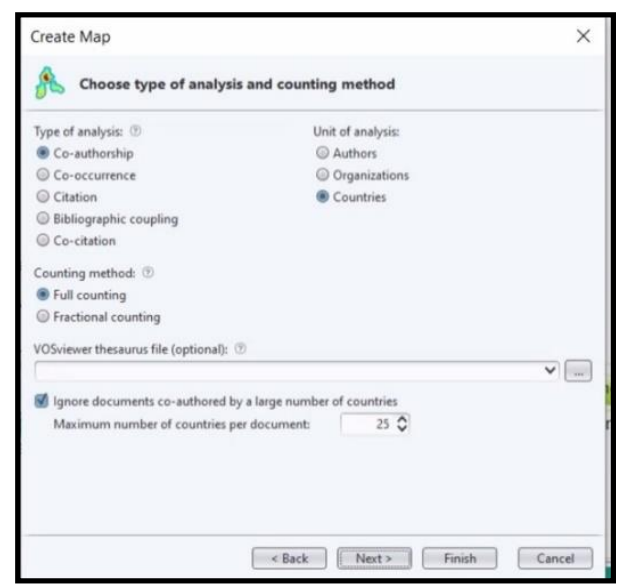

Figure 7. Display of the Vosviewer Co-Authorship Feature

(Source: Data processing on Scopus, 19 June 2021)

Figure 8 can explain the location where the researcher comes from which is shown in the mapping of the affiliation of the researcher's location. According to the existing results, the research focused on India, Switzerland, Australia, Canada, and Malaysia. It can also be seen that there are no connecting lines from the mapping results which indicate that the authors have never done research together. 




Figure 8. Results of Mapping the Co-Authorship Network

(Source: Data processing on Scopus, 19 June 2021)

\section{Research Trend Analysis}

In the analysis of research trends, the co-occurrence feature in VOSviewer is used to find out which keywords often appear in the study, both in the title and abstract, the display of the cooccurrence feature is shown in Figure 9. The occurrence of these keywords is then grouped into the year of release article. It is used to find out which keywords appear frequently in a given year and indicate ongoing research trends.

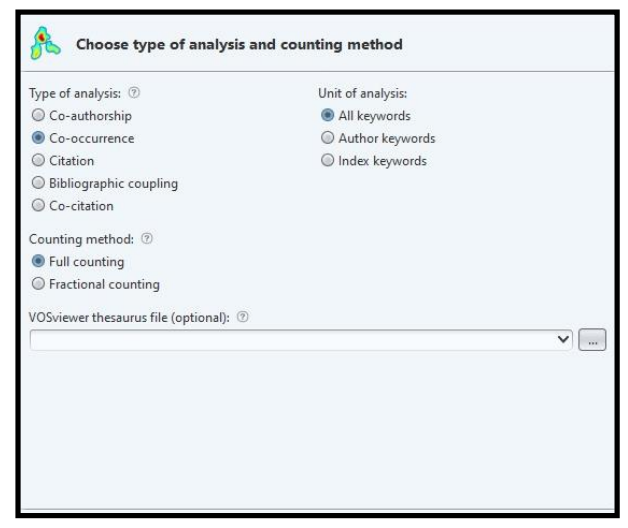

Figure 9. Display of the Vosviewer Co-Occurrence feature

(Source: Data processing on Scopus, 19 June 2021)

Based on the data in Figure 10, it can be seen that around 2008-2021 several main keywords emerged. These are grouped by year which is indicated by the color spectrum at the bottom right corner. The purple color indicates between the years 2008-2009, the blue color indicates between the years 2010-2012, the green color indicates between the years 2013-2018, and the yellow color indicates between the years 20192021. Between 2008-2014, several topics emerged as trends, including: entrepreneurship, women, economic and social entrepreneurship, application, business enterprise, barriers. In the next period there was an increase in the number of keywords that appeared, although there were also the same keywords in the previous period. Several keywords that have emerged between 2015-2018 are entrepreneurial intention, women entrepreneurs, gender, ICT, information systems, decision making, innovation, based 
entrepreneurship, economic and social effects, developing countries, social networking (online), electronic commerce, economic progress, economic empowerment, human computer interaction, social media application. The increase in the number of keywords is also in line with the increase in the number of publications. In 2019-2021, several new keywords emerged, namely ecosystem approach, economic empowerment, energy, entrepreneurial intention. In the development of trends that have occurred over the last 13 years, it can also be seen that the discussion topics indicated by keywords are always being added, this shows that this topic is still worthy of research and can still be developed further in the future.

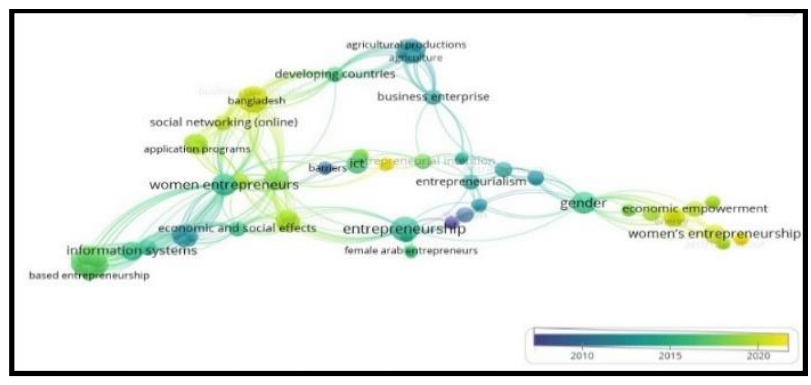

Figure 10. Primary Keywords by Year

(Source: Data processing on Scopus, 19 June 2021)

\section{Bibliometric Co-Citation Analysis}

At the co-citation analysis stage, you will visualize the references used by the documents being tested or observed. References will be linked if they are used in the same article. In this analysis, co-citation is visualized based on the name of the reference author. So, if there is a reference author's name that has a connecting line with others, it shows that there is also the name of the reference author with the name of another reference author in other articles. It should be noted that in this co-citation analysis there are 24 data articles used after selecting the abstract. The following are the results of the co-citation network mapping that has been carried out on VOSviewer.

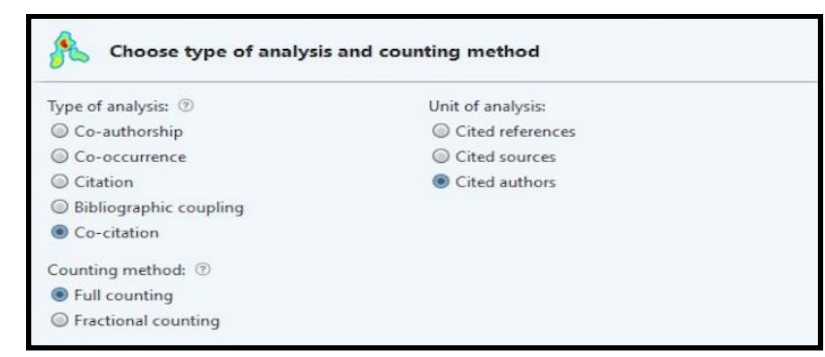

Figure 11. Display of the Vosviewer Co-Citation feature

(Source: Data processing on Scopus, 19 June 2021)

The mapping of the Co-Sitation network that is formed has the criteria that one author publishes at least two articles. Figure 12 shows that there are more than 15 authors' names that are interconnected, visualized by a line that is interconnected between the point of the author's name and the point of other authors. Clusters can be visually divided into 7 color clusters consisting of red, yellow, green, blue, turquoise, and orange. The dominant reference is in the green cluster, according to CSV Scopus data there are as many as 30 references to author names by Brush c.g. with a discussion that focuses on the cross-section and role of Information Technology for women entrepreneurs, then the red cluster by Marlow, S. which focuses on the perspective and development of women entrepreneurs in various fields of Technology, the yellow cluster by Aldrich, H. and Minniti, M, the blue cluster by Buttner's author, uh, the purple cluster by Guney-Frahm and the turquoise cluster that has minimal dashes to the others, namely Warhurst, Ekinsmyth and Lewis, 
P., and the orange cluster which has only 1 dash with the names of other authors and there is one reference to the author's name which has no relationship at all with the reference to the name of another author, namely by the author's name Gobinath.

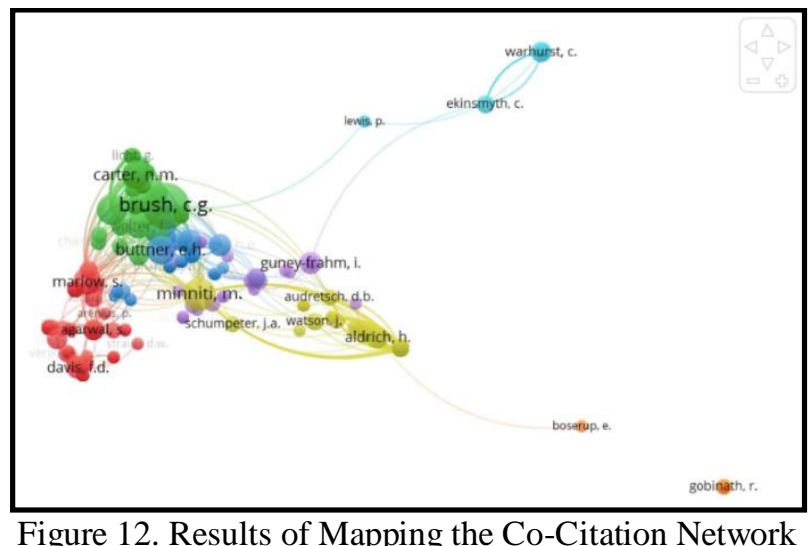

Figure 12. Results of Mapping the Co-Citation Network

(Source: Data processing on Scopus, 19 June 2021)

Summary table of the bibliometric analysis findings is in the appendix.

\section{Conclusion and Implications}

Based on the results of the analysis that has been carried out, the following are conclusions from trend research that have been done:

a) From research on women's entrepreneurship in technology (women in tech) shows a positive trend from year to year indicating that this research is increasingly in demand to be discussed.

b) The most contributing countries to the results of women in technology research from Scopus data are the United States or the United States with 10 articles.

c) From the results of the co-citation analysis, it can be concluded that the discussion articles on women in tech have 7 clusters with the dominant reference being the green cluster because there are 30 references to the author's name Brush c.g. by discussing the role of information technology for women entrepreneurs.

d) The results of the Co-Occurance analysis, it can be concluded that from year to year along with the large number of studies, it also indicates the number of keywords that appear.

In this research, there are limitations that become the limitations of research in the preparation of related papers, the author's team only does how women's entrepreneurship is in developing countries, not all countries in the world in addition we chose to focus on women's entrepreneurship related to technology. And the author gets access to the journal only through the Scopus web, thus limiting the number of articles that are the author's reference for further analysis. We recommend for future research to conduct a bibliometric study that focuses only on a specific country or other region. This can be used to find out more deeply how research is developing in certain fields. The related region can be the Continent of Asia, Europe, America, and others. Future research can also conduct bibliometric studies using combined data from various journal database providers, for example: Scopus, Web of Science, SINTA, PubMed, and so on to obtain data sets with a more qualified amount of bibliographic information. Bibliometric studies on other topics or disciplines are still needed because bibliometric studies still have a lot of potential for developing research topics.

\section{References}

AW, S. (2017). Female Entrepreneurs in Developing Countries: A Comparative with Developed Countries as Explorative Study. Arabian Journal of Business and Management Review, 1-5. 
Agustiyani. (2014). Pengaruh Pembelajaran Mata Kuliah Kewirausahaan terhadap Minat Mahasiswa untuk Berwirausaha (Studi Kasus Pada Mahasiswa Program Studi Ekonomi Islam Angkatan Tahun 2011 UIN Walisongo Semarang). Universitas Islam Negeri Walisongo, Ekonomi Islam. Semarang: Walisongo Institutional Repository.

Andrizal. (2018). Analisis Faktor-Faktor yang Mempengaruhi Pendapatan Wirausaha Wanita dalam Usaha Makanan Ringan di Kota Payakumbuh. Universitas Andalas, Ilmu Ekonomi. Padang: Scholar Unand.

Badan Pusat Statistik. (2019). Statistik Telekomunikasi Indonesia. Jakarta: Badan Pusat Statistik.

Buttner, E. H., \& Moore, D. P. (1997). Women entrepreneurs: Moving beyond the glass ceiling. Journal of Small Business Management, 34-36.

Crittenden, V. L., Crittenden, W. F., \& Ajjan, H. (2019). Empowering women micro-entrepreneurs in emerging economies: The role of information communications technology. Journal of Business Research, 191-203.

De Looze, M., \& Lemarie, J. (1997). Corpus Relevance Through Co-Word Analysis: An Application to Plants. Scientometrics, 267-280.

Donner, J., \& Escobari, M. X. (2010). A review of evidence on mobile use by micro and small enterprises in developing countries. Journal of International Development, 22(5), 641-658.

Glanzel, W. (2003). Bibliometrics as a Research Field: A Course on Theory and Application of Bibliometric Indicators. from Retrieved Gesearch https://www.researchgate.net/publication/242406991_Bibliometrics_as_a_research_field_A_cours e_on_theory_and_application_of_bibliometric_indicators

Himawanto. (2015). Kajian Bibliometrik terhadap Artikel Bidang Teknologi Minyak dan Gas Bumi di Indonesia (Bibliometric Study of the Oil and Gas Technology Field in Indonesia). Jurnal Dokumentasi dan Informasi.

Hinson, R. E. (2011). Banking the poor: The role of mobiles. Journal of Financial Services Marketing, 320-333.

Kshetri, D. \&. (2003). Gender and internet usage : the internet encyclopedia. New York: Wiley.

Liputan6.com. (2018, Maret 08). Survei: Wanita di Negara Maju Lebih Berkembang Jadi Pengusaha. Retrieved Juni 17, 2021, from Liputan 6: https://www.liputan6.com/bisnis/read/3354830/surveiwanita-di-negara-maju-lebih-berkembang-jadi-pengusaha

Nuryudi. (2016). Analisis Bibliometrika Islam: Studi Kasus Dokumentasi Publikasi Ilmiah di UIN Syarif Hidayatullah Jakarta. Jurnal Komunikasi dan Informasi Perpustakaan, 41-55.

Prasojo, L. D. (2011). Teknologi Informasi Pendidikan. Yogyakarta: Gava Media.

Roy, S., \& Manna, S. (2014). Women in Entrepreneurship: Issues of Motivation and Choice of Business. Journal of Entrepreneurship \& Management, 1-8.

Royani, Y., \& Idhani, D. (2018). Analisis Bibliometrik Jurnal Marine Research in Indonesia. Jurnal Marine Research in Indonesia, 65. 